ISSN (Online) 2722-1083,

VOL 3 NO 1 OKTOBER 2021

\title{
PENYULUHAN DAN PEMERIKSAAN KADAR HAEMOGLOBIN SERTA PEMERIKSAAN TELUR CACING SOIL TRANSMITTED HELMINTHS (STH) PADA ANAK SD N 105302 DI DESA TANGKAHAN KEC. NAMORAMBE KAB. DELI SERDANG
}

\author{
Liza Mutia, Karolina br Surbakti, Selamat Riadi \\ Poltekkes Medan Jurusan Teknologi Laboratorium Medis \\ (korespondensi: liza.mutia1009@gmail.com)
}

\begin{abstract}
ABSTRAK
Infeksi STH (Soil transmitted helmiths) biasanya tidak menyebabkan kematian, tetapi menyebabkan infeksi kronis dan morbiditas yang berkepanjangan terutama pada anak SD karena pada usia SD anak beresiko tinggi terinfeksi kecacingan, hal ini disebakan pada usia SD belum mengerti untuk menjaga kebersihan dirinya dan juga pada usia ini anak lebih banyak beraktifitas dengan tanah. Metode pelaksanan pengabdian maasyarakaat ini adalah dengan metode pembelajaran bercerita yang dapat mengundang rasa ingin tahu dan ketertarikan anak terhadap sesuatu yang menjadi materi pembelajaran. Metode ini diharapakan menarik minat anak dengan menunjukkan ekspresi anak SD Negeri 105302 Desa Tangakahan Kecamatan Namorambe Kabupaten Deli serdang. Peserta berjumlah 76 siswa SD dengan rincian siswa kls IV berjumlah 24 orang (31\%), Kelas V berjumlah 21 orang (28\%) dan kelas VI berjumlah 31 orang (41\%), Setelah dilakukan pemeriksaan telur cacing STH pada faeces/ tinja ditemukan 3 siswa (4 \%) Siswa terinfeksi kecacingan dan sebanyak 73 siswa 96\%) siswa tidak terinfeksi kecacingan. Pada pemeriksaan kadar Haemoglobin seluruh siswa memiliki kadar Haemoglobin (Hb)normal. Dari hasil pengabdian masyarakat dapat disimpulkan bahwa siswa SD tersebut sudah dapat meningkatkan pengetahuan tentang manfaat kebersihan diri dan bahaya kecacingan.
\end{abstract}

Kata Kunci : STH, Anak SD, Kebersihan diri

\begin{abstract}
Soil Transmitted Helminths (STH) infection usually does not cause death, but causes chronic infection and prolonged morbidity, especially in elementary school children because at elementary school age children are at high risk of infection with worms, this is because elementary school age does not understand how to maintain personal hygiene and also at the age of This child is more active with the ground. The method of implementing this community service is the storytelling learning method that can invite children's curiosity and interest in something that becomes the learning material. This method is expected to attract children's interest by showing the expressions of the children of SD Negeri 105302, Tangakahan Village, Namorambe District, Deli Serdang Regency. Participants were 76 elementary school students with details of 24 Class IV students (31\%), 21 Class V students (28\%) and 31 Class VI students (41\%). After examining the STH worm eggs in the faeces, this service found 3 students (4\%) students are infected with worms and as many as 73 students (96\%) students are not infected with worms. On the examination of haemoglobin levels, all students had normal haemoglobin $(\mathrm{Hb})$ levels. From the results of community service, it can be concluded that these elementary students have been able to increase knowledge about the benefits of personal hygiene and the dangers of worms.
\end{abstract}

Keywords : STH, elementary School student, personal hygiene

\section{PENDAHULUAN}

Penyakit kecacingan merupakan salah satu penyakit neglected disease atau penyakit yang kurang mendapat perhatian tetapi masih banyak terjadi di masyarakat (Silver, et al., 2018). Penyakit ini disebabkan oleh infeksi cacing kelompok Soil Transmitted Helminths (STH) yaitu kelompok cacing yang siklus hidupnya melalui tanah yang merupakan penyakit tersembunyi (silent disease) dan kurang terpantau oleh petugas kesehatan (Nurjana, et al., 2014). STH yang paling penting terdiri cacing gelang
(Ascaris lumbricoides), cacing cambuk (Trichuris trichiura) dan cacing tambang (Necator americanus atau Ancylostoma duodenale).

Infeksi STH biasanya tidak menyebabkan kematian, tetapi menyebabkan infeksi kronis dan morbiditas yang berkepanjangan (Silver, et al., 2018). Infeksi STH menimbulkan kerugian yang cukup besar bagi penderita dan keluarganya. Kecacingan dapat menyebabkan anemia (kurang darah), berat bayi lahir rendah, gangguan ibu bersalin, lemas, mengantuk, malas belajar, IQ menurun, prestasi dan produktivitas 
ISSN (Online) 2722-1083, VOL 3 NO 1 OKTOBER 2021

menurun (Depkes, 2010). Morbiditas infeksi STH yang tersembunyi tidak hanya sangat merugikan kesehatan seorang individu, tetapi juga telah terbukti mempengaruhi perkembangan ekonomi (Silver, et al., 2018). Satu ekor cacing dapat menghisap darah, karbohidrat dan protein dari tubuh manusia. Cacing gelang menghisap 0,14 gram karbohidrat dan 0,035 gram protein, cacing cambuk menghisap $0,005 \mathrm{~mL}$ darah, dan cacing tambang menghisap $0,2 \mathrm{~mL}$ darah.(Dinkes, 2010), Dengan kata lain beratnya infeksi kecacingan ini akan menjadi salah satu penentu terjadi penurunan kadar hemoglobin pada penderita kecacingan.

Berdasarkan survey yang dilakukan pelaksana pengabdi masyarakat bahwa SD Negeri 105302 Desa Tangakahan Kecamatan Namorambe Kabupaten Deli Serdang memiliki lingkungan dan sanitasi yang kurang baik, dimana halaman samping SD dibuat menjadi tempat pembungan sampah dan lahan warga, serta lapangan SD masih bertanah. Siswa SD tersebut juga mempunyai kebiasaan bermain dengan tanah, makan tanpa mencuci tangan dan jajan sembarangan, serta umumnya mata pencaharian orang tua siswa SD ini adalah berkebun sehingga aktifitas anak setelah pulang dari sekolah membantu orangtua nya di kebun tentunya ini mendorong terjadi nya infeksi kecacingan pada anak SD dan ditambahkan pula dengan kurangnya pengetahuan siswa SD Negeri 105302 Desa Tangakahan Kecamatan Namorambe Kabupaten Deli Serdang untuk menjaga kebersihan diri.

Pada pengabdian masyarakat ini digunakan metode pembelajaran bercerita yang dapat mengundang rasa ingin tahu dan ketertarikan anak terhadap sesuatu yang menjadi materi pembelajaran. Metode ini diharapakan menarik minat anak dengan menunjukkan ekspresi, media, serta penggunaan teknik ucapan dalam bercerita. Sehingga dengan bercerita dapat memindahkan cerita dari pencerita kepada penyimak atau pendengar (Kumaro, 2015 dalam Subyantoro, 2013). Selain kegiatan penyuluhan, pengabdian masyarakat ini disertai dengan pemeriksaan kadar haemoglobin dan pemeriksaan telur cacing STH pada feses murid SD Negeri 105302 Desa Tangakahan Kecamatan Namorambe Kabupaten

\section{Deli Serdang}

\section{METODE PELAKSANAAN}

Pelaksanaan pengabdian masyarakat ini dilaksanakan di UPT SPF SD Negeri 105302 Desa Tangakahan Kecamatan Namorambe Kabupaten Deli serdang. Sosialisasi pengabdian masyarakat ini diberikan pada Murid SD dan penyuluhan akan dilakukaan oleh anggota pengabdiaan masyarakat yaitu para Dosen Teknologi Laboratorium Kesehatan Poltekkes Kemenkes Medan.

Pelaksanaan pengabdian masyarakat dilaksanakan selama tiga hari, dimana urutan kegiatan pengabdian masyarakat ini adalah :

1. Hari pertama pot feses yang telah diberi label dibagikan ke murid di SD Negeri 105302 Desa Tangakahan Kecamatan Namorambe Kabupaten Deli serdang dilanjutkan dengan kegiatan penyuluhan kesehatan tentang penyakit kecacingan. Penyuluhan ini menggunakan metode pembelajaran bercerita, materi disajikan dalam bentuk cerita sehingga diharapkan dapat mengundang rasa ingin tahu dan ketertarikan anak terhadap materi pembelajaran penyakit cacingan dan dilakukan juga sosialisasi cara pengumpulan feses pagi guru dan murid.

2. Pada hari kedua pot yang berisi feses dikumpulkan. Setelah pengumpulan pot feses, dilanjutkan dengan pemeriksaan kadar haemoglobin pada anak SD tersebut.

Kemudian dilakukan tahap evaluasi yang diberikan kepada murid SD dengan pemberian kuesioner untuk mengetahui sejauh mana pengetahuan murid SD tersebut tentang materi penyuluhan kecacingan.

3. Pot feses kemudian dibawa ke laboratorium Parasitologi Jurusan Teknnologi Laboratorium Medik Poltekkes Kemenkes Medan untuk dilakukan pemeriksaan telur cacing.Metode pemeriksaan telur cacing menggunakan metode natif (langsung). Prinsip dari pemeriksaan ini dilakukan dengan mencampurkan feses dengan eosin 2\% lalu diperiksa di bawah mikroskop dengan perbesaran 100x. Penggunaan eosin 2\% digunakan untuk memperjelas perbedaan telur- 
ISSN (Online) 2722-1083,

VOL 3 NO 1 OKTOBER 2021

telur cacing dengan kotoran sekitarnya (Dwinata et al, 2017).

\section{HASIL}

Dari hasil pemeriksaan kesehatan pada pengabdian masyaarakat yang diadakaan anak di SD Negeri 105302 Desa Tangakahan Kecamatan Namorambe Kabupaten Deli Serdang disusun dalam bentuk tabulasi. Adapun beberapa variable tambahan yang menjadi pembahasan dalam laporan hasil pengabdian masyarakat ini adalah Umur dan Jenis Kelamin

Gambaran Karakteristik Jumlah Peserta Pengabdian Masyarakat Pada SD Negeri 105302 Desa Tangakahan Kecamatan Namorambe Kabupaten Deli Serdang

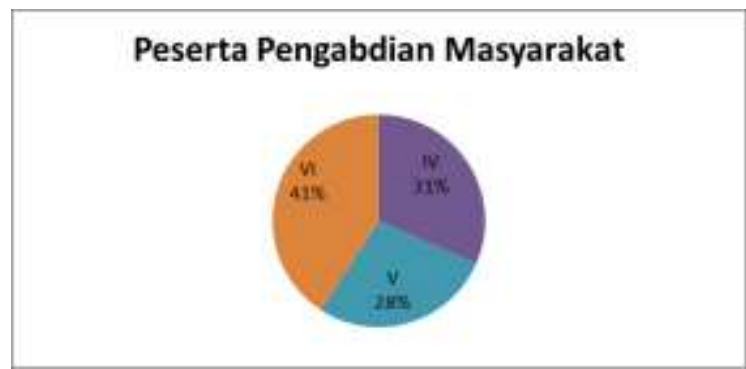

Dari diagram diatas terlihat Peserta pengabdian masyarakat siswa SD Negeri 105302 Desa Tangakahan Kecamatan Namorambe Kabupaten Deli Serdang berjumlah 76 orang $(100 \%)$ dengan rincian siswa kls IV berjumlah 24 orang (31 \%), Kelas V berjumlah 21 orang $(28 \%)$ dan kelaas VI berjumlah 31 orang $(41 \%)$

Gambaran Karakteristik Peserta Pengabdian Masyarakat Pada SD Negeri 105302 Desa Tangakahan Kecamatan Namorambe Kabupaten Deli Serdang Berdasarkan Jenis Kelamin

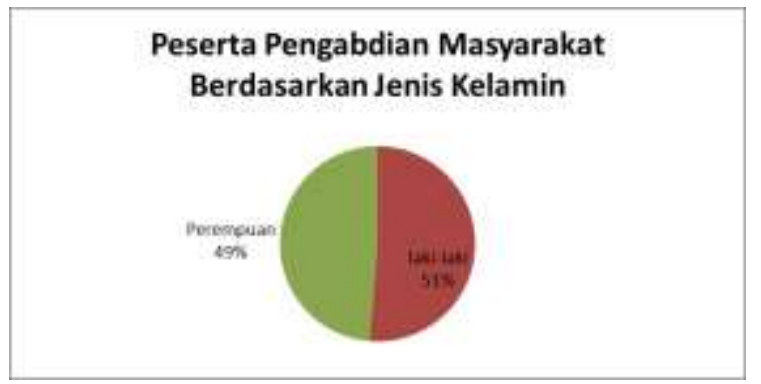

Dari diagram diatas terlihat Peserta pengabdian masyarakat siswa SD Negeri 105302 Desa Tangakahan Kecamatan Namorambe Kabupaten Deli Serdang berdasarkan jenis kelamin laki-laki 39 Siswa (51\%) dan Perempuan 37 siswa (49\%)

Gambaran Karakteristik Peserta Pengabdian Masyarakat Pada SD Negeri 105302 Desa Tangakahan Kecamatan Namorambe Kabupaten Deli Serdang Berdasarkan Usia

\section{Peserta Pengabdian Masyarakat} Berdasarkan Usia

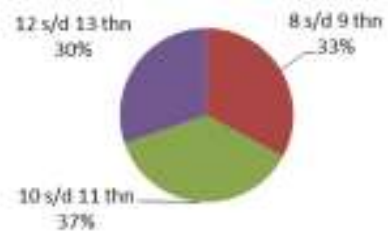

Dari diagram diatas terlihat Peserta pengabdian masyarakat siswa SD Negeri 105302 Desa Tangakahan Kecamatan Namorambe Kabupaten Deli Serdang berdasarkan jenis usia 8 sampai dengan 9 tahun sebanyak 25 siswa (33\%), 10 sampai dengan 11 tahun sebanyak 28 Siswa (37\%) dan usia 12 sampai dengan 13 tahun sebanyak 23 siswa (30\%)

Gambaran Hasil Pemeriksaan Telur Cacing STH pada Anak SD Negeri 105302 Desa Tangakahan Kecamatan Namorambe Kabupaten Deli Serdang 
ISSN (Online) 2722-1083,

VOL 3 NO 1 OKTOBER 2021

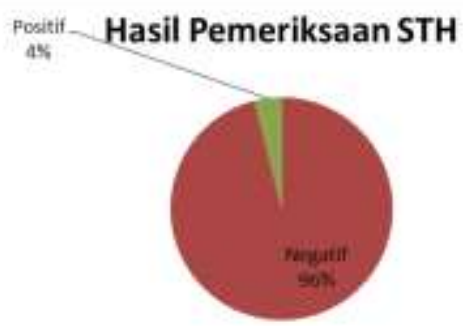

Dari diagram diatas terlihat hasil pemeriksaan telur cacing STH pada siswa SD Negeri 105302 Desa Tangakahan Kecamatan Namorambe Kabupaten Deli Serdang ditemukan 3 siswa (4\%) Siswa terinfeksi kecacingan dan sebanyak 73 siswa 96\%) siswa tidak terinfeksi kecacingaan

Gambaran Hasil Pemeriksaan Kadar Haemoglobin pada Anak SD Negeri 105302 Desa Tangakahan Kecamatan Namorambe Kabupaten Deli Serdang

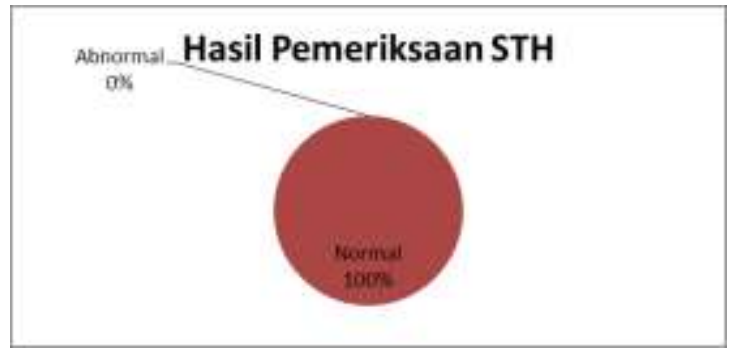

Dari diagram diatas terlihat hasil pemeriksaan Haemoglobin pada siswa SD Negeri 105302 Desa Tangakahan Kecamatan Namorambe Kabupaten Deli Serdang didapatkaan 76 siswa (100\%) memiliki haemoglobin normal.

Tabulasi Silang Infeksi Soil Transmitted Helminths Dengan Kadar Haemoglobin Pada Siswa SD Negeri 105302 Desa Tangakahan Kecamatan Namorambe Kabupaten Deli Serdang

\begin{tabular}{|c|c|c|c|}
\hline \multirow{3}{*}{$\begin{array}{l}\text { Infeksi } \\
\text { STH }\end{array}$} & \multicolumn{2}{|c|}{ Kadar Haemoglobin } & \\
\hline & Normal & $\begin{array}{l}\text { Tidak } \\
\text { Normal }\end{array}$ & Jumlah \\
\hline & $\mathrm{n}$ & $\mathrm{n}$ & $\mathrm{n}$ \\
\hline
\end{tabular}

\begin{tabular}{lcccccc} 
Positif & 3 & 3,95 & 0 & 0 & 3 & 3,95 \\
\hline Negatif & 73 & 96,05 & 0 & 0 & $3^{7}$ & 96,05 \\
\hline Jumlah & 76 & 100 & 0 & 0 & $6^{7}$ & 100 \\
\hline
\end{tabular}

Dari tabel setelah dilakukan pemeriksaan diketahui bahwa dari 76 orang siswa SD Negeri 105302 Desa Tangakahan Kecamatan Namorambe Kabupaten Deli Serdang (dari semua siswa yang terinfeksi cacing STH ataupun tidak), semuanya memilik kadar Haemoglobin Normal

Tabulasi Silang Infeksi Soil Transmitted Helminths Dengan Usia Siswa SD Negeri 105302 Desa Tangakahan Kecamatan Namorambe Kabupaten Deli Serdang

\begin{tabular}{lccccccccc}
\hline & \multicolumn{9}{c}{ Usia } \\
\cline { 2 - 8 } $\begin{array}{l}\text { Infeksi } \\
\text { STH }\end{array}$ & $\begin{array}{l}8-9 \\
\text { (thn) }\end{array}$ & \multicolumn{9}{c}{$\begin{array}{l}10- \\
11(\mathrm{thn})\end{array}$} & $12-13(\mathrm{thn})$ & \multicolumn{2}{c}{ Jumlah } \\
\cline { 2 - 8 } & $\mathrm{n}$ & $\%$ & $\mathrm{n}$ & $\%$ & $\mathrm{n}$ & $\%$ & $\mathrm{n}$ & $\%$ \\
\hline Positif & 3 & 12,5 & 0 & 0 & 0 & 0 & 3 & 3,95 \\
\hline Negatif & 21 & 87,5 & 21 & 100 & 31 & 100 & 73 & 96,05 \\
\hline Jumlah & 24 & 100 & 21 & 100 & 31 & 100 & 76 & 100 \\
\hline
\end{tabular}

Dari tabel diketahui bahwa dari 76 orang siswa SD Negeri 105302 Desa Tangakahan Kecamatan Namorambe Kabupaten Deli serdang ditemukan 3 siswa $(3,95 \%)$ yang positif terinfeksi cacing STH, sedangkan yang tidak terinfeksi sebanyak 73 siswa $(96,05 \%)$. Dari ketiga siswa yang terinfeksi cacing ini berusia antara 8 sampai dengan 9 Tahun.

Tabulasi Silang Infeksi Soil Transmitted Helminths Dengan Jenis Kelamin Siswa SD Negeri 105302 Desa Tangakahan Kecamatan Namorambe Kabupaten Deli Serdang

Infeksi Jenis Kelamin 
ISSN (Online) 2722-1083, VOL 3 NO 1 OKTOBER 2021

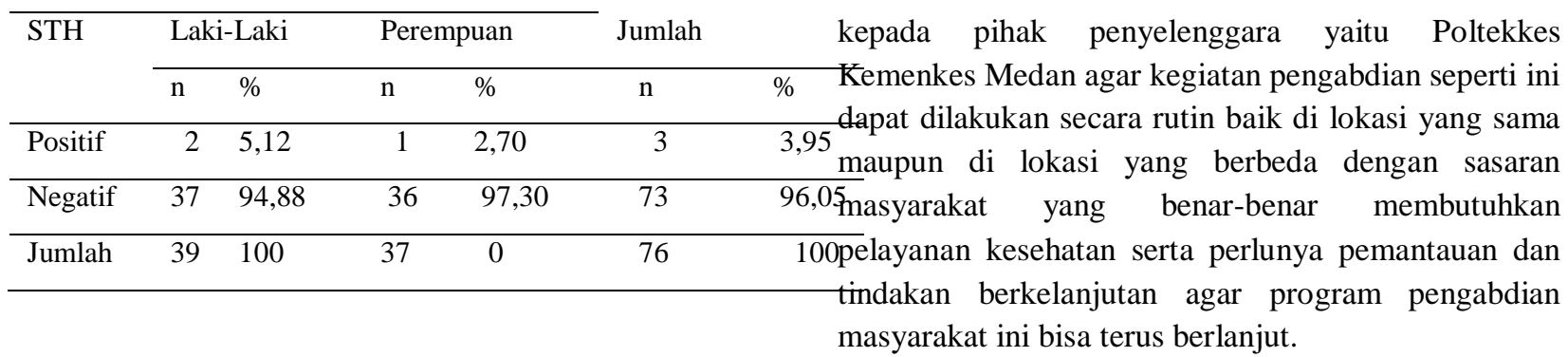

Dari tabel diketahui bahwa dari 76 orang siswa SD Negeri 105302 Desa Tangakahan Kecamatan Namorambe Kabupaten Deli serdang ditemukan 3 siswa $(3,95 \%)$ yang positif terinfeksi cacing STH dimana 2 siswa berjenis kelamin laki-laki dan 1 siswa berjenis kelamin perempuan.

\section{KESIMPULAN DAN SARAN}

Dari hasil pengabdian masyarakat yang dilakukan di UPT SPF SD Negeri 105302 Desa Tangakahan Kecamatan Namorambe Kabupaten Deli Serdang maka dapat disimpulkan sebagai berikut:

1. Kegiatan pengabdian masyarakat di UPT SPF SD Negeri 105302 Desa Tangakahan Kecamatan Namorambe Kabupaten Deli Serdang dapat berjalan dengan baik.

2. Pengetahuan siswa di UPT SPF SD Negeri 105302 Desa Tangakahan Kecamatan Namorambe Kabupaten Deli Serdang tentang kecacinga menjadi meningkat lebih baik, hal ini terlihat dari antusiasnya siswa dalam penyuluhan pengabdian masyarakat ini dan hanya 3 siswa (4\%) SD Negeri 105302 Desa Tangakahan Kecamatan Namorambe Kabupaten Deli Serdang yang ditemukan terinfeksi kecacingan, dimana dari 3 siswa yang terinfeksi kecacingan 2 siswa berjenis kelamin laik-laki dan 1 siswa berjenis kelamin perempuan

3. Kadar Haemoglobin seluruh Siswa UPT SPF SD Negeri 105302 Desa Tangakahan Kecamatan Namorambe Kabupaten Deli Serdang dalam keadaan normal.

Dari hasil pengabdian masyarakat yang dilakukan di UPT SPF SD Negeri 105302 Desa Tangakahan Kecamatan Namorambe Kabupaten Deli Serdang maka pelaksana pengabdian masyarakat menyarankan

\section{DAFTAR PUSTAKA}

Anuar, TS., Salleh, FM., Moktar, N. Soil Transmitted Helminth Infections and Associated Risk Factors inThree Orang Asli Tribes in Peninsular Malaysia. Scientific Reports. 2014: 1-4.

Bethony, J., Brooker, S., Albonico, M., Geiger, SM., Loukas A., Diemert, D., Hotez, P. SoiltransmittedHelminth Infections: Ascariasis, Trichuriasis, and Hookworm. The Lancet. 2016. 367: 1521-1534.

Departemen Kesehatan. 2010. Penyakit Kecacingan Masih Dianggap Sepele.

Dwinata, IM., Apsari, IAP., Suratma, A., Oka, IBM. 2017. Modul Identifikasi Parasit Cacing. Fakultas Kedokteran Hewan Universitas Udayana.

Jourdan, PM., et al. Soil Transmitted Helminth Infections. The Lancet. Januari 2018; 391(10117): 252

Kumoro, I. 2015. Analisis Urgensi Metode Pembelajaran Bercerita Bagi Perkembangan Empati Anak di TK Dharma Wanita Kendal Tahun Ajaran 2015/2016. Prosiding Seminar Nasional Pendidikan Universitas Sebelas Maret Surakarta dan ISPI Wilayah Jawa Tengah: 129-131.

Nurjana, MA., et al. Pengetahuan dan Perilaku Anak Sekolah tentang Kecacingan di Beberapa Sekolah Dasar di Kecamatan Labuan Kabupaten Donggala Tahun 2012. Ejournal litbang depkes. 2014

Serra, LM. Prevention of Soil-Transmitted Helminth Infection. J Glob Infect Dis. 2011 Apr-Jun; 3(2): 175182.

Silver ZA., et al. Geographical Distribution of Soil Transmitted Helminths and The Effects of Community Type in South Asia and South East Asia - A systematic review. PLOS Neglected Tropical Diseases.2018; 12(1): 1-13. 
ISSN (Online) 2722-1083,

VOL 3 No 1 OKTOBER 2021

WHO. 2005. Deworming for health and development. Reports on the third global meeting of the partners for parasite control. World Health Organization.

WHO. 2016. Framework for control and prevention of soil-transmitted helminthiases in the WHO European Region 2016-2020. World Health Organization 